\title{
Türkçe Öğretmenlerinin Yazınsal Metinleri Anlamaya Yönelik Etkinlikler ile İlgili Görüşlerinin İncelenmesi ${ }^{1}$
}

\section{Zeynep CIN ŞEKER²}

APA: Cin Şeker, Z. (2018). Türkçe Öğretmenlerinin Yazınsal Metinleri Anlamaya Yönelik Etkinlikler ile İlgili Görüşlerinin İncelenmesi. RumeliDE Dil ve Edebiyat Araştırmaları Dergisi, (12), 122-137.

DOI: $10.29000 /$ rumelide.472761

\section{$\ddot{O} \mathbf{z}$}

Bu çalışmanın konusu, Türkçe öğretmenlerinin Türkçe ders kitaplarında yer alan yazınsal metinleri anlamaya yönelik etkinlikler ile ilgili görüşlerini incelemektir. Çalışmanın konusu bağlamında, Türkçe öğretmenlerinin metni anlamaya yönelik etkinliklere ilişkin görüşlerini, hâlihazırda uygulanan metni anlama çalışmalarına alternatif yaklaşım önerilerini belirlemek ve bu görüşler doğrultusunda bir değerlendirme yapmak amaçlanmıştır. Çalı̧̧ada nitel araştırma deseni kullanılmıştır. Çalışmanın araştırma grubu, Erzurum il merkezinde bulunan ortaokullarda görev yapan Türkçe öğretmenleri arasından uygun örnekleme yöntemi ile belirlenmiştir. Çalışmanın verileri ise beş açık uçlu soru ile oluşturulan "Yarı Yapılandırılmış Öğretmen Görüşme Formu" ile toplanmıştır. Araştırmanın sonucunda Türkçe öğretmenlerinin, yazınsal metinleri çözümlemeye yönelik etkinliklerin önemli olduğunu düşündükleri ancak hâlihazırda uygulanan metin çözümleme çalışmalarını yetersiz ve eksik buldukları görülmüştür. Öğretmenlerin bu çalışmalara alternatif olarak öğrencilerin eleştirel ve yaratıcı düşünme becerilerini geliştirecek, gerçek hayatla bağlantılı çalışmalara yöneldikleri sonucuna ulaşılmıştır.

Anahtar kelimeler: Türkçe eğitimi, yazınsal metin, öğretmen görüşleri.

\section{Investigation of Turkish Teachers' Views on the Activities Related to Understanding of Literary Texts}

\begin{abstract}
The aim of this study is to determine the Turkish teachers' opinions related to the activities to comprehend the text, to suggest alternative approaches to the comprehension studies and to make an evaluation in line with these opinions. Qualitative research design has been used in the study. The research group of the study has been adjusted by the convenience sampling method among Turkish teachers working in secondary schools in Erzurum city center. The data of the study have been collected by "Semi-Structured Teacher Interview Form" formed by five open-ended questions. As a result of the study, it has been understood that Turkish teachers thought that activities aimed at analyzing literary texts were important but they found the text analysis studies inadequate and incomplete. As an alternative to these studies, it has been concluded that the students are oriented towards real life related studies which will develop their critical and creative thinking skills.
\end{abstract}

Bu araştırma, 23-25.03.2018 tarihleri arasında düzenlenen Uluslararası Eğitim ve Bilim Kongresi’nde sözlü bildiri olarak sunulmuştur.

2 Arş. Gör. Dr., Atatürk Üniversitesi, Kâzım Karabekir Eğitim Fakültesi, Türkçe ve Sosyal Bilimler Eğitimi Bölümü, Türkçe Eğitimi ABD, zeynep.seker@atauni.edu.tr, ORCID ID: 00oo-0002-0294-2961 [Makale kayt tarihi: 1.10.2018-kabul tarihi: 14.10 .2018$]$ 
Key words: Turkish language education, literary texts, Turkish teachers' opinions.

\section{Giriş}

Türkçe eğitiminin en önemli amaçlarından biri ana dili eğitimi vermek yani öğrencilerin edindiği dili, dil edincine dönüştürmektir. Beceri dersi olan Türkçe derslerinin en önemli işlevlerinden biri anlama ve anlatma becerilerini geliştirmektir. Öğrencilerin anlatma becerilerinin gelişmesi ise anlama becerilerinin gelişmesiyle doğrudan ilişkilidir.

Öğrencilerin dil ve düşünme becerilerini geliştirme sürecinde en sık kullanılan araç Türkçe ders kitapları ve dolayısıyla bu ders kitaplarında yer alan metinlerdir. Seçilen nitelikli metinler dili etkili kullanma, eleştirel ve yaratıcı düşünme, iletişim kurma, problem çözme, karar verme, araştırma gibi temel becerilerin ve okuma, yazma, konuşma, dinleme temel dil becerilerinin gelişimine katkı sağlaması ve aynı zamanda dilin kurallarının işlevsel olarak sezdirileceği bir ortam olma özelliği göstermesi bakımından önem taşımaktadır. Başka bir ifadeyle dil edinimini dil edincine dönüştürme sürecinde, öğrencilerin anlama becerilerinin geliştirilmesinde en önemli aracın metinler olduğu söylenebilir.

Yapılandırıcı eğitim anlayışının benimsenmesiyle birlikte Türkçe öğretiminde tematik yaklaşım ve etkinlik temelli öğretim önem kazanmıştır. Geleneksel dil öğretim anlayışının aksine metin bir amaç olarak değil araç olarak değerlendirilmiştir. "Yapılandırıcı yaklaşıma göre metin amaç olmamalı, metnin derinlemesine incelenmesi ve içindeki bilgilerin öğrencilere ezberletilmesi yoluna gidilmemelidir." (Güneş, 2013, s. 623). Günümüzde çağdaş dil çalışmalarından hareketle iletişimin birimi metin olarak kabul edilmektedir. Dilin somutlaştırılması ve iletişimin gerçekleşmesi metinle sağlanır. Bu bağlamda dil öğretimi için metinlerin temel araç olarak kullanılması doğru bir yaklaşımdır (Dilidüzgün, 2008, s. 145).

Türkçe öğretiminde kullanılacak metinlerin, genellikle doğruları aktarma ve öğretme amacında olmayan, öğrencilerin duygu ve düşünce üretmesine imkân veren metinler olmasının öğrencilerin yaratıcı düşünme becerilerini geliştirme açısından önemli olduğu düşünülmektedir. Bu bağlamda öğrencilerin Türkçe derslerinde yazınsal metinlerle karşılaşmaları gerekmektedir. "Yazınsal metinler estetik özellikleriyle hem çözümleyici ve eleştirel düşünmeyi hem de duygusal zekâyı ve yaratıcılı̆̆ geliştirici bir gizilgüç içeriyorlar. Bu gizilgüçten yararlanabilme, gençlerin ilgisini çekebilecek olan konuları içeren ve estetik bir değer taşıyan metinlerin seçilmesini koşulladığı gibi bu metinleri okuma ve çözümleme yöntemlerine de egemen olmayı gerektiriyor." (İpşiroğlu, 2002, s. 80)

Yazınsal metinler, okurun farklı bir ortama girmesini zorunlu kılar yani ona bir sorumluluk yükler. "Okura yüklenen bu sorumluluk, bilinçli bir okuma eylemiyle, anlamın oluşmasına ortak olmak, metni yeniden yaratmak gibi bilişsel, duyuşsal ve devinişsel davranışların yaşama geçirilmesini gerekli kılar.” (Sever, 2007, s. 5). Yazınsal metinde, günlük iletişimde kullanılan doğal dile göre işlenmiş, kurgulanmış bir dil kullanılır. Estetik işlevin baskın olduğu bu dili kurgulamak ve böyle bir dil ile oluşturulan anlama ulaşmak üst düzey zihin becerileri gerektirir. Bu nedenle ana dili eğitimi bir düşünce eğitimi olarak düzenlenmeli ve uygulanmalıdır.

Rifat (1978, s. 101) yazınsal metinlerin yazınsallık özelliği ile dili arasındaki ilişkiyi şöyle açıklar:

Yazınsal yapıtların özgüllüğü, dilyetisinin anlatım olanakları eşliğinde kullanılmasıyla belirlenir; bu açıdan, doğal dile ilişkin anlatım yöntemlerinden bir uzaklaşma, bir sapma görülür yazınsal yapıtlarda. Gerçekten de yazınsal anlatım, yalnızca, dış gerçekteki birtakım olguların aktarılmasını sağlayan ya da iç dünyaya özgü duyarlıkların iletilmesini gerçekleştiren yalın bir araç değildir. 
Yazınsal dil, dış gerçeği aktarmak gibi salt bir bildirişim işlevi yüklenmez. Gösterilen (içerik) kadar, onu taşıyan gösteren (biçim) de önemlidir. ... Yazarın, öncelikle yaratmayı amaçladığı dil, yeni gösterenler desteğiyle yeni gösterilenler oluştururken, yazınsallık, dizeler, satırlar hatta sözcüklerden değil sözcükler arası bağıntılardan, kesitlerarası ilişkilerden doğar. Yazınsal yapıt, bu açıdan, doğal dil dizgesinden kalkılarak oluşturulmuş ikincil bir dizgeye özgü işlevler alanıdır.

Bu bağlamda yazınsal metinleri çözümlemek sadece dilsel yapıları belirlemekten, sözcük veya cümlelerin ifade ettiklerini ortaya çıkarmaktan daha fazla bir çaba gerektirir. Yazınsal metinlerle karşılaşan öğrencilerin dilsel yapılardan hareketle metnin anlam katmanlarına ulaşmasını sağlamanın, biçim ve anlam arasındaki ilişkiyi sezmeleri açısından önemli olduğu söylenebilir.

Yazınsal metinlerin Türkçe öğretiminde kullanılmasını gerekli kılan özelliklerinden bir diğeri çok anlamlı olmalarıdır. Bu çok anlamlı yapıyı çözmek için daha ayrıntılı ve metin türüne özgü bir okuma çabası gerekir. Öğrenci, metnin anlam katmanlarını ortaya çıkarmak için metinde yer alan her anlam biriminin işlevini fark etmelidir. Bu bağlamda yazınsal metinlerin öğrencilerin okuma ve anlama becerilerinin gelişmesine katkıda bulunacağı ve dil bilgisi özelliklerine işlevsel bakabilme becerisini kazanacağı düşünülmektedir.

Öğrencilerin dil ve düşünme becerilerini geliştirme bağlamında ders kitaplarına seçilen yazınsal metinler kadar bu metinleri anlamaya yönelik hazırlanan etkinlikler de önemlidir. Beceri kazandırma ve bu becerileri geliştirmeyi amaçlayan Türkçe derslerinde bu amaçlara istenilen seviyede ulaşılabilmesi, becerilerin kazanılması uygulama sürecine öğrencilerin ancak etkin bir şekilde katılmalarıyla mümkün olacaktır. Bu bağlamda öğrencilerin ders kitaplarında yer alan yazınsal metinleri anlamaya yönelik bütüncül bakış açısına sahip etkinliklerle karşılaşmaları ve metne kendilerini yakın hissetmeleri önem taşır. Günay'a (2007, s. 52) göre "Metnin iç yapısını, kendine özgü dokusunu ayrıntılı olarak incelemek, okurun okuma isteğini artıracak bir durumdur. ... Okuduğu metinlerin erişilmez olduğu yönündeki düşüncesi değişecek, kendisi de metnin iç yapısını ve devingenliğini bildiğinden kolaylıkla bu tür etkinliğe yönelebilecektir.”.

Yazınsal metinleri anlamaya yönelik etkinliklerin uygulama basamaklarında en önemli bileşenlerden biri Türkçe öğretmenidir. Türkçe eğitiminin, Türkçe ders ve çalışma kitaplarında yer alan yazınsal metinleri anlamaya yönelik etkinlikler ile amaçladıklarına ulaşabilmesinde uygulayıcı konumundaki Türkçe öğretmenlerinin yaklaşımları ve görüşleri alınmalıdır. Bu doğrultuda Türkçe öğretmenlerinin süreci değerlendirmelerini sağlamak ve böylece sürece katkılarını ortaya koymak büyük önem taşımaktadır.

Alan yazın incelendiğinde yazınsal metinlerin kullanımının dil becerilerine etkisini, Türkçe derslerinde kullanılan etkinlikleri inceleyen çalışmaların yapıldığı görülmektedir. Karasakaloğlu ve Bulut (2012); Chen (2006); Şahinli (2008); Palamut (2008); Göçer (2010); Kolaç, Demir ve Karadağ (2012); Dilidüzgün (2010); Shazu (2014); Ramani (2014) bu çalışmalara örnek gösterilebilir. Bunun yanında Türkçe öğretmenlerinin ders kitabı, dil becerileri ile ilgili etkinlikler, dil bilgisi öğretimi, Türkçe Öğretim Programı ile ilgili görüşlerine başvurulan çalışmalar da yapılmıştır. Aykaç (2007); Arıcı (2005); Aydın (1999); Şahin (2008); Susar Kırmızı ve Akkaya (2009); Epçaçan ve Okçu (2010); Kılıç ve Akçay (2011); Güven (2011); Göçer ve Tabak (2012); Yaylı ve Solak (2014) bu tür çalışmalardandır. Alan yazınında dil becerilerine yönelik tasarlanan ve ders kitaplarında yer alan etkinliklerin öğretmen görüşleri doğrultusunda değerlendirildiği çalışmalar yapılmış ancak yazınsal metinleri çözümlemeye yönelik olarak tasarlanan etkinliklerin Türkçe öğretmenlerinin görüşleri doğrultusunda değerlendirildiği çalışmalara rastlanmamıştır. Ana dili eğitiminde, dil ve düşünme becerilerini geliştirme bağlamında en işlevsel ortam ve araç olma özelliği gösteren yazınsal metinleri çözümleme etkinlikleri büyük önem 
taşımaktadır. Etkinliklerin niteliğini ve uygulanabilirliğini ortaya çıkarabilecek en önemli unsurlardan biri ise uygulayıcı konumundaki öğretmenlerdir. Bu araştırmanın amacı da Türkçe öğretmenlerinin yazınsal metinleri anlamaya yönelik etkinlikler ile ilgili görüşlerini, öğretmenlerin etkinlikler ile ilgili önerilerini ve var olan etkinliklere alternatif olarak kullandıkları etkinlikleri belirlemektir. $\mathrm{Bu}$ doğrultuda çalışmada şu sorulara cevap aranmıştır:

1. Türkçe öğretmenlerinin, Türkçe ders kitaplarında yazınsal metinleri anlamaya yönelik etkinliklerin yer almasına ilişkin görüşleri nelerdir?

2. Türkçe öğretmenlerinin hâlihazırda Türkçe ders kitaplarında yer alan yazınsal metinleri anlamaya yönelik etkinliklere ilişkin görüşleri nelerdir?

3. Türkçe öğretmenlerinin, dil bilgisi etkinliklerinin yazınsal metinleri çözümleme etkinlikleri üzerindeki etkisine ilişkin görüşleri nelerdir?

4. Türkçe öğretmenlerinin, Türkçe ders kitaplarında yer alan yazınsal metinleri anlamaya yönelik etkinliklerin belirli bir metin çözümleme kuramı çerçevesinde tasarlanmasına ilişkin görüşleri nelerdir?

5. Türkçe öğretmenlerinin, yazınsal metinleri anlamaya yönelik etkinliklere ilişkin ek çalışma yapma durumları nedir?

\section{Yöntem}

\section{Araştırmanın Deseni}

$\mathrm{Bu}$ çalışmada nitel araştırma deseni kullanılmıştır. Nitel araştırma, gözlem, görüşme ve doküman analizi gibi nitel veri toplama yöntemlerinin kullanıldığı, algıların ve olayların doğal ortamda gerçekçi ve bütüncül bir biçimde ortaya konmasına yönelik nitel bir sürecin izlendiği araştırmadır (Yıldırım ve Şimşek, 2011, s. 39). Bu araştırma da Türkçe öğretmenlerinin yazınsal metinleri çözümlemeye yönelik etkinliklerle ilgili görüşlerine ulaşmayı ve bu görüşleri incelemeyi amaçladığı için nitel araştırma deseni tercih edilmiştir.

\section{Araştırma grubu}

$\mathrm{Bu}$ çalışmanın araştırma grubunu Erzurum il merkezindeki ortaokullarda görev yapan ve amaçsal örnekleme yöntemlerinden uygun örnekleme tekniği ile seçilen 19 Türkçe öğretmeni oluşturmuştur. Uygun örnekleme yöntemi araştırmacının kolayca ulaşabileceği bir örneklemden verilerin toplanması olarak ifade edilmektedir. Araştırmacı ihtiyaç duyduğu büyüklükteki bir gruba ulaşana kadar en ulaşlabilir olan yanıtlayıcılardan başlamak üzere örneklemini oluşturmaya başlar ya da en ulaşılabilir ve maksimum tasarruf sağlayacak bir durum, örnek üzerinde çalışır (Büyüköztürk, Çakmak, Akgün, Karadeniz ve Demirel, 2015, s. 92). Araştırmaya katılan Türkçe öğretmenlerinin çalışma sürelerine ilişkin bilgiler Tablo 1'de sunulmuştur:

\section{Tablo 1. Öğretmenlerin çalışma sürelerine ilişkin veriler}

Çalışma süreleri $\quad \mathrm{N} \quad \%$




\begin{tabular}{lll}
\hline $1-5$ & 1 & 5,26 \\
$6-10$ & 5 & 26,31 \\
$11-15$ & 3 & 15,78 \\
$16-20$ & 6 & 31,57 \\
20 yll ve üzeri & 4 & 21,05 \\
\hline Toplam & 19 & 100 \\
\hline
\end{tabular}

\section{Veri Toplama Aracı}

Yazınsal metinlere yönelik olarak Türkçe ders ve çalışma kitaplarında yer alan etkinliklerle ilgili öğretmen görüşlerini incelemeyi amaçlayan bu çalışmanın verileri araştırmacı tarafından geliştirilen "Yarı Yapılandırılmış Görüşme Formu" ile toplanmıştır. Formda beş açık uçlu soruya yer verilmiştir. Yarı yapılandırılmış görüşme formundaki sorular 3 Türkçe eğitimi alan uzmanına sunulmuş ve uzmanlardan alınan görüşler doğrultusunda formdaki bazı sorular düzenlenmiş bazıları da değiştirilmiştir. Uzman görüşleri doğrultusunda düzenlenen form, uygulama sürecine katılmayan 2 Türkçe öğretmenine uygulanmıştır. Uygulama sonucunda öğretmenlerin farklı iki soruya benzer cevaplar verdikleri saptanmıştır. $\mathrm{Bu}$ nedenle öğretmenler tarafından benzer görülen iki soru birleştirilmiş ve forma son biçimi verilmiştir.

\section{Verilerin Analizi}

Araştırmanın verileri nitel araştırma veri analizi yöntemlerinden içerik analizi ile çözümlenmiştir. İçerik analizi, belirli kurallara dayalı kodlamalarla bir metnin bazı sözcüklerinin daha küçük içerik kategorileri ile özetlediği sistematik, yinelenebilir bir teknik olarak tanımlanır (Büyüköztürk, Kılıç Çakmak, Akgün, Karadeniz ve Demirel, 2015, s. 240). Öğretmenlerin görüşleri, oluşturulan temalar doğrultusunda belirlenmiş ve gruplandırılmıştır. Elde edilen veriler tablo biçiminde ve frekans-yüzde değerleri dikkate alınarak sunulmuştur.

\section{Bulgular}

1. Türkçe öğretmenlerinin Türkçe ders kitaplarında yazınsal metinleri anlamaya yönelik etkinliklerin yer almasına ilişkin düşünceleri

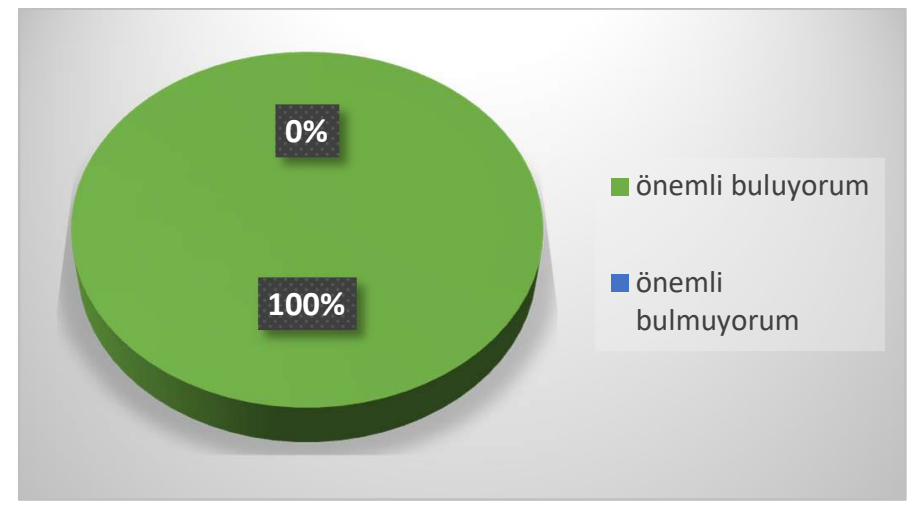


Şekil 1. Türkçe öğretmenlerinin "Türkçe ders kitaplarında yazınsal metinleri anlamaya yönelik etkinliklere yer verilmesini önemli buluyor musunuz?” sorusu ile ilgili görüşleri

Şekil 1'e göre Türkçe öğretmenlerinin tamamının yazınsal metinleri anlamaya yönelik etkinlikleri önemli buldukları ve Türkçe ders materyallerinde bu etkinliklere yer verilmesini istedikleri anlaşılmaktadır.

Tablo 2. Türkçe öğretmenlerinin, Türkçe ders kitaplarında yazınsal metinleri anlamaya yönelik etkinliklerin yer almasına iliş̧in görüş̧leri

\begin{tabular}{|c|c|c|}
\hline & $\mathbf{f}$ & $\%$ \\
\hline Okuma-anlama-yorumlama becerilerinin geliştirilmesine katkı sağlar & 11 & 28.9 \\
\hline Türkçe dersinin bütün öğrenme alanlarının geliştirilmesi için önemlidir. & 1 & 2.6 \\
\hline $\begin{array}{l}\text { Anlama becerisinin gelişmesine dolayısıyla anlatma becerisinin gelişmesine katkı } \\
\text { sağlar. }\end{array}$ & 3 & 7.8 \\
\hline $\begin{array}{l}\text { Kelimelerin anlamını bağlam içerisinde öğrenerek, kelime dağarcıklarını } \\
\text { geliştirir. }\end{array}$ & 3 & 7.8 \\
\hline Metinlerin yüzeysel değil derinlemesine incelenmesine firsat verir. & 2 & 5.2 \\
\hline Öğrencileri düşünmeye sevk eder. & 2 & 5.2 \\
\hline Öğrencilerin sorunlara farklı çözüm önerileri sunmasına yardımcı olur. & 1 & 2.6 \\
\hline Dilin doğru ve güzel bir biçimde kullanılmasına katkı sağlar. & 1 & 2.6 \\
\hline Öğrencilerin kendilerini ifade etmelerini kolaylaştırır. & 4 & 10.5 \\
\hline Dil zenginliğini artırmak açısından önemlidir. & 1 & 2.6 \\
\hline $\begin{array}{l}\text { Her metne özgü etkinlikler tasarlandığında öğrencilerin birçok becerisini } \\
\text { geliştirir. }\end{array}$ & 1 & 2.6 \\
\hline Merak duygusunu ve öğrenme isteğini artırır. & 1 & 2.6 \\
\hline Zihinsel becerilerini kullanma oranlarını artırır. & 2 & 5.2 \\
\hline Dil bilgisi seviyelerinin gelişmesine katkı sağlar. & 1 & 2.6 \\
\hline Metni kavrama ve çözümleme becerilerini geliştirir. & 3 & 7.8 \\
\hline Öğrencilerin hafiza becerilerini geliştirir. & 1 & 2.6 \\
\hline Toplam & 38 & 100 \\
\hline
\end{tabular}

Tablo 2'ye göre Türkçe öğretmenlerinin yazınsal metinleri anlamaya yönelik etkinlikleri, öğrencilerin okuma-anlama ve yorumlama becerilerini geliştirme, kendilerini ifade etme, metni kavrama ve çözümleme becerilerini geliştirme, anlama becerilerinin gelişmesiyle anlatma becerilerini ve kelime dağarcıklarını geliştirme, metinleri derinlemesine incelemesine firsat verme bağlamında önemli buldukları görülmektedir. 
2. Türkçe öğretmenlerinin hâlihazırda Türkçe ders kitaplarında yer alan yazınsal metinleri anlamaya yönelik etkinliklerin yeterliliğine ilişkin görüşleri

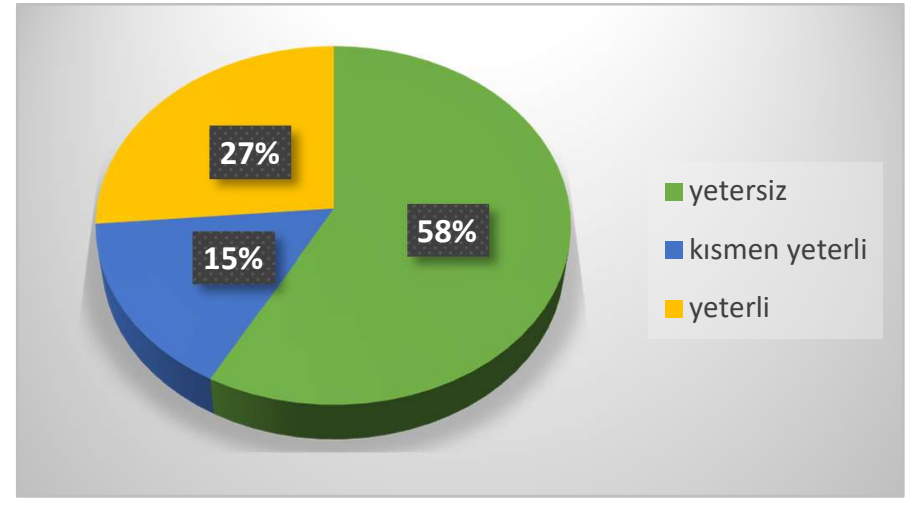

Şekil 2. Türkçe öğretmenlerinin "Hâlihazırda Türkçe ders kitaplarında yer alan yazınsal metinleri anlamaya yönelik etkinlikleri yeterli buluyor musunuz?" sorusu ile ilgili görüşleri

Şekil 2’ye göre ders kitaplarında yer alan yazınsal metinlere yönelik etkinlikleri, Türkçe öğretmenlerinin \%58’inin yetersiz, \%27'sinin yeterli ve \%15’inin ise kısmen yeterli bulduğu görülmektedir.

Tablo 3. Türkçe öğretmenlerinin hâlihazırda Türkçe ders kitaplarında yer alan yazınsal metinleri anlamaya yönelik etkinliklere ilişkin görüşleri

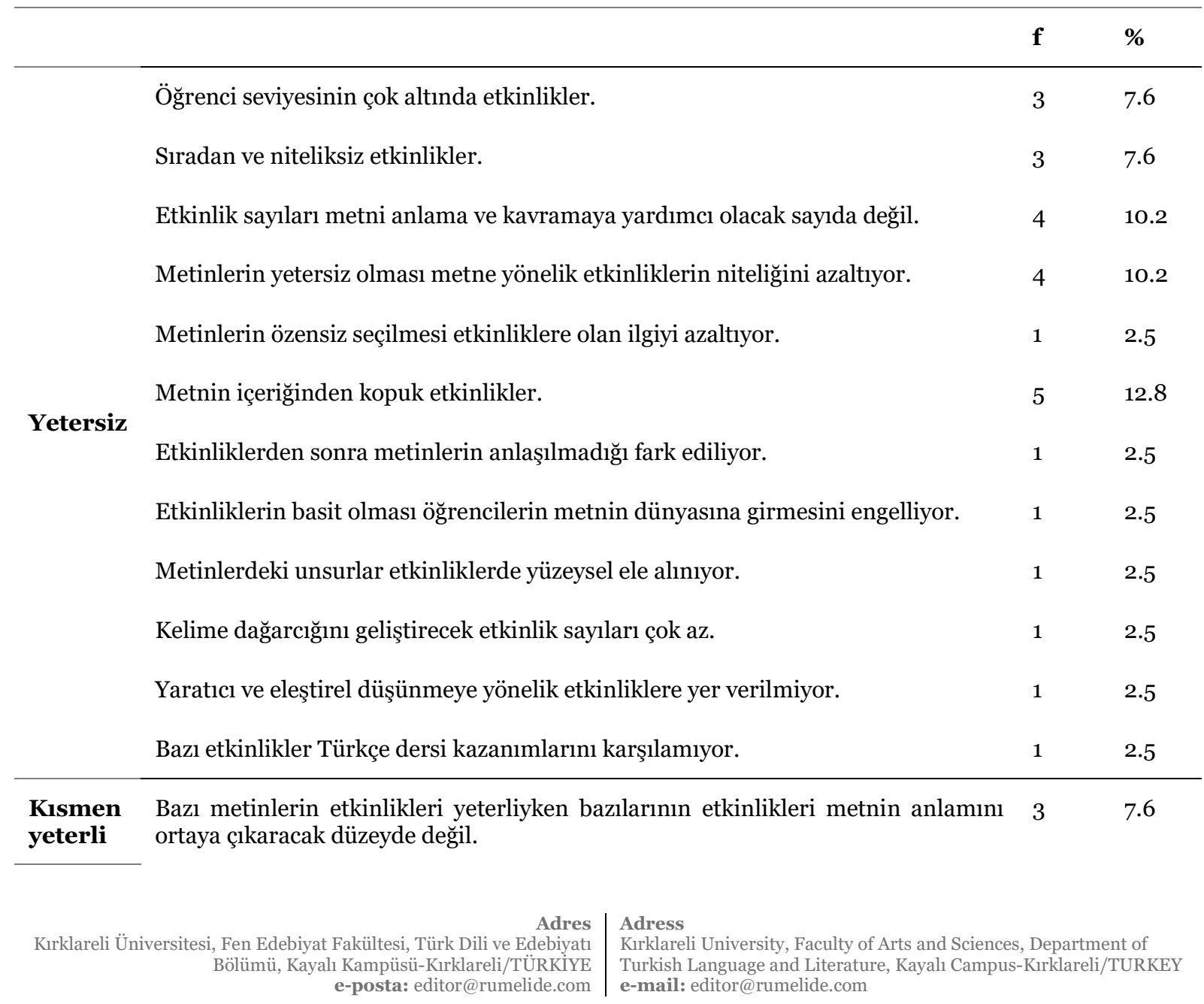




\begin{tabular}{|c|c|c|c|}
\hline & Sinıf seviyesine göre etkinliklerin yeterliliği değişiyor. & 1 & 2.5 \\
\hline \multirow{5}{*}{ Yeterli } & Her öğrencinin anlayabileceği ve kolayca cevap verebileceği etkinlikler & 2 & 5.1 \\
\hline & Kelime dağarcığını geliştiren etkinlikler & 1 & 2.5 \\
\hline & Metnin türünü kavratacak nitelikte etkinlikler & 2 & 5.1 \\
\hline & Öğrencilerin metni anlaması açısından yeterli & 3 & 7.6 \\
\hline & Müfredata uygun & 1 & 2.5 \\
\hline Toplam & & 39 & 100 \\
\hline
\end{tabular}

Hâlihazırda Türkçe ders kitaplarında yer alan yazınsal metinleri anlamaya yönelik etkinlikleri yetersiz bulan öğretmenler, etkinliklerin metnin içeriğinden kopuk, öğrenci seviyesinin altında ve öğrencilerin hemen cevap verebilecekleri etkinlikler olduğunu, metni kavramaya yetecek sayıda ve nitelikte etkinlikler olmadığını ifade etmişlerdir. Öğretmenlerin dikkat çektiği bir diğer önemli nokta ise niteliksiz metin seçiminin etkinliklere olan ilgiyi azaltmasıdır. Türkçe ders kitaplarında yer alan yazınsal metinleri anlamaya yönelik etkinlikleri kısmen yeterli bulan öğretmenler, bazı metinlere yönelik etkinlikleri yeterli bulurken bazılarınınkini metnin anlamını ortaya çıarma noktasında yetersiz bulmuşlardır. Aynı zamanda etkinliklerin yeterliliğinin sınıf seviyesine göre değişkenlik gösterdiğini ifade etmişlerdir. Türkçe ders kitaplarında yer alan yazınsal metinleri anlamaya yönelik etkinlikleri yeterli bulan öğretmenler ise etkinliklerin kelime dağarcığını geliştirecek, metnin türünü kavratacak, metnin anlaşılmasını sağlayacak nitelikte olduklarını ifade etmiş ve bu nedenlerle etkinlikleri yeterli bulmuşlardır. Etkinliklerin müfredata uygun olması ve öğrencilerin etkinliklere kolay cevap verebilmeleri de öğretmenlerin belirttiği diğer gerekçelerdir.

\section{Türkçe öğretmenlerinin, dil bilgisi etkinliklerinin yazınsal metinleri çözümleme etkinlikleri üzerindeki etkisine ilişkin görüşleri}

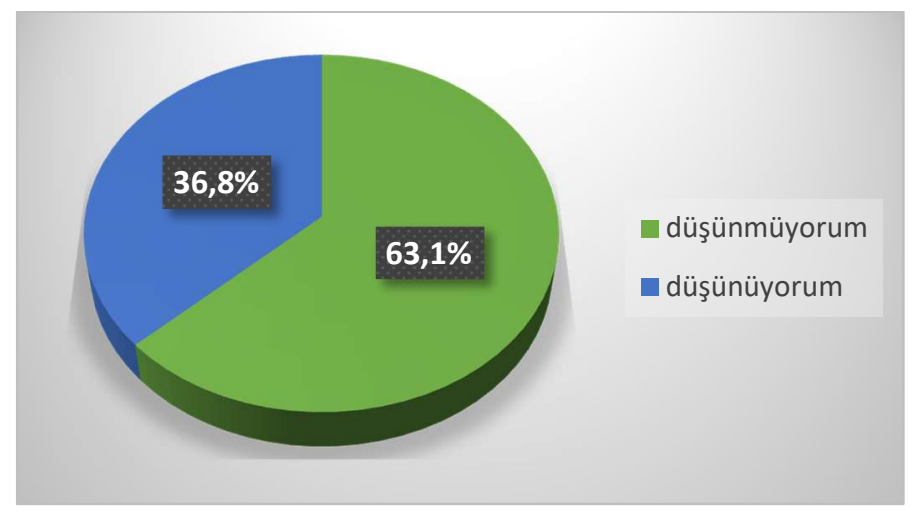

\section{Şekil 3. Türkçe öğretmenlerinin, "Türkçe ders kitaplarında yer alan dil bilgisi etkinliklerinin yazınsal metinleri çözümleme etkinlikleri üzerinde etkili olduğunu düşünüyor musunuz?" sorusu ile ilgili görüşleri}

Şekil 3’e göre Türkçe öğretmenlerinin \%63,1'inin dil bilgisi etkinliklerinin yazınsal metinleri çözümleme etkinlikleri üzerinde etkili olmadığını, \%36,8’inin ise etkili olduğunu ifade ettiği görülmektedir. 
Tablo 4. Türkçe öğretmenlerinin Türkçe ders kitaplarında yer alan dil bilgisi etkinliklerinin yazınsal metinleri çözümleme etkinlikleri üzerindeki etkisine ilişkin görüşleri

\begin{tabular}{|c|c|c|c|}
\hline & & $\mathbf{f}$ & $\%$ \\
\hline \multirow{7}{*}{ Düşünmüyorum } & Sadece dil bilgisi kazanımlarına yönelik etkinlikler & 1 & $3 \cdot 5$ \\
\hline & $\begin{array}{l}\text { Dil bilgisi etkinlikleri metin çözümlemesine yardımcı olacak nitelikte } \\
\text { değil }\end{array}$ & 4 & 14.2 \\
\hline & Dil bilgisi etkinliklerinde kullanılan cümleler metinden bağımsız & 5 & 17.8 \\
\hline & $\begin{array}{l}\text { Dil bilgisi etkinlikleri anlama becerisini geliştirmekten çok gramer } \\
\text { bilgisini geliştirmeye ve kural öğretmeye yönelik }\end{array}$ & 3 & 10.7 \\
\hline & Dil bilgisi etkinlikleri yüzeysel ve yetersiz & 5 & 17.8 \\
\hline & $\begin{array}{l}\text { Bir dil bilgisi konusu bir metinle ilişkilendirildiği için etkinlikler } \\
\text { yetersiz }\end{array}$ & 2 & 7.1 \\
\hline & Dil bilgisi etkinlikleri metni anlamlandırma açısından düzensiz & 1 & $3 \cdot 5$ \\
\hline \multirow{4}{*}{ Düşünüyorum } & $\begin{array}{l}\text { Öğrencilerin metindeki sözcük ve cümlelerin yapısını kavramasını } \\
\text { sağlıyor. }\end{array}$ & 1 & $3 \cdot 5$ \\
\hline & $\begin{array}{l}\text { Öğrencilerin dil bilgilerini (dil bilgisi kurallarını bilme) geliştirerek } \\
\text { metni anlamlandırma ve çözümlemelerine yardımcı oluyor. }\end{array}$ & 3 & 10.7 \\
\hline & $\begin{array}{l}\text { Metni kavramalarını ve metinden cümlelerle dil bilgisini daha iyi } \\
\text { çözümlemelerini sağllyor. }\end{array}$ & 2 & 7.1 \\
\hline & Dil bilgisi konularına giriş sağlıyor & 1 & $3 \cdot 5$ \\
\hline Toplam & & 28 & 100 \\
\hline
\end{tabular}

Dil bilgisi etkinliklerinin yazınsal metinleri çözümleme etkinlikleri üzerinde etkili olduğunu düşünmeyen öğretmenler gerekçe olarak dil bilgisi etkinliklerinin yüzeysel olduğunu, etkinliklerde kullanılan cümlelerin metinlerden seçilmediğini ve etkinliklerin metni anlama becerisine katkıda bulunmaktan çok dil bilgisini geliştirmeyi ve kural öğretmeyi amaçladığını ifade etmişlerdir. Bu doğrultuda öğretmenlerin dil bilgisi etkinliklerinin öğrencilerin anlama becerilerine katkıda bulunmasını önemli buldukları ve dil bilgisi etkinliklerinde bu ilişkinin hissettirilmediğini düşündükleri görülmektedir.

Dil bilgisi etkinliklerinin yazınsal metinleri çözümleme etkinlikleri üzerinde etkili olduğunu düşünen öğretmenler ise bu etkinliklerin öğrencilerin dil bilgisi kurallarını öğrenmelerini sağladığını, dil bilgilerini geliştirerek metni anlama ve çözümleme süreçlerine katkıda bulunduğunu, metinden seçilen cümlelerin öğrencilerin dil bilgisini daha iyi kavramalarını sağladığını ifade etmişlerdir. Öğretmenlerin bu görüşlerinden hareketle öğrencilerin dil bilgisi kurallarını öğrenmeleri ile metni kavramaları arasında ilişki kurdukları anlaşılmaktadır.

4. Türkçe öğretmenlerinin, Türkçe ders kitaplarında yer alan yazınsal metinleri anlamaya yönelik etkinliklerin belirli bir metin çözümleme kuramı çerçevesinde tasarlanmasına ilişkin görüşleri 


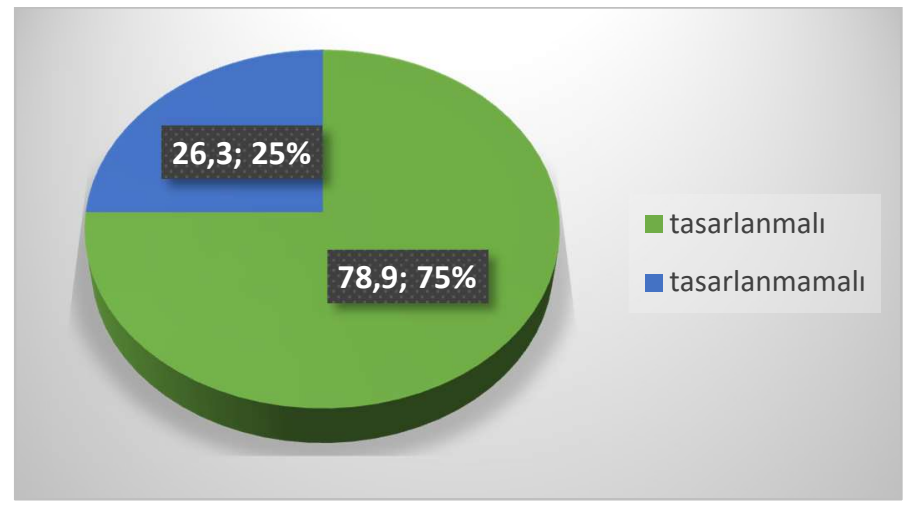

Şekil 4. Türkçe öğretmenlerinin "Türkçe derslerinde kullanılan yazınsal metinleri anlamaya yönelik etkinlikler belirli bir metin çözümleme kuramı çerçevesinde tasarlanmalı mı?" sorusu ile ilgili görüşleri

Şekil 4'e göre Türkçe öğretmenlerinin \%78,9'unun yazınsal metinleri anlamaya yönelik etkinliklerin belirli bir metin çözümleme kuramı esas alınarak tasarlanması, \%26,3’ünün ise tasarlanmaması gerektiğini ifade ettikleri görülmektedir.

Tablo 5. Türkçe öğretmenlerinin Türkçe derslerinde kullanılan yazınsal metinleri anlamaya yönelik etkinliklerin belirli bir metin çözümleme kuramı çerçevesinde tasarlanmasına ilişkin görüsşleri

\begin{tabular}{|c|c|c|c|c|}
\hline & & & $\mathbf{f}$ & $\%$ \\
\hline \multirow{10}{*}{ Tasarlanmalı } & \multicolumn{2}{|c|}{ Metne uygun kuramların seçimi metni kavramayı kolaylaştırır. } & 4 & $15 \cdot 3$ \\
\hline & \multicolumn{2}{|l|}{ Sınıflar arasında eşitlik sağlar. } & 1 & 3.8 \\
\hline & \multicolumn{2}{|l|}{ Metne odaklanma gücünü geliştirir. } & 4 & $15 \cdot 3$ \\
\hline & \multicolumn{2}{|c|}{ Dersin düzenli ve disiplinli işlenmesini sağlar. } & 4 & $15 \cdot 3$ \\
\hline & \multicolumn{2}{|c|}{ Her metnin kendine özel kazanımlarının ortaya çıkmasını sağlar. } & 2 & 7.6 \\
\hline & \multicolumn{2}{|c|}{ Metin çözümleme sürecini kolaylaştırır. } & 2 & 7.6 \\
\hline & \multicolumn{2}{|c|}{ Dikkati metin dışına değil metne odaklar. } & 1 & 3.8 \\
\hline & \multicolumn{2}{|c|}{ Gelişigüzel, içi boş etkinlikleri engeller. } & 1 & 3.8 \\
\hline & \multicolumn{2}{|c|}{ Anlama-yorumlama etkinliğinin niteliğini artırır. } & 1 & 3.8 \\
\hline & \multicolumn{2}{|c|}{ Metin çözümleme sürecinde belirli bir sıra ve akış sağlar. } & 1 & 3.8 \\
\hline \multirow{3}{*}{ Tasarlanmamalı } & \multicolumn{2}{|c|}{$\begin{array}{l}\text { Her metne yönelik aynı kuramın kullanılması metnin yapısının göz ardı } \\
\text { edilmesine neden olur. }\end{array}$} & 2 & 7.6 \\
\hline & \multicolumn{2}{|c|}{ Metin çözümleme sürecinde öğretmen ve öğrenciyi kısıtlar. } & 1 & 3.8 \\
\hline & \multicolumn{2}{|c|}{ Öğrencinin düşünce dünyasını daraltır. } & 1 & 3.8 \\
\hline \multicolumn{2}{|c|}{$\begin{array}{r}\text { Adres } \\
\text { Kırklareli Üniversitesi, Fen Edebiyat Fakültesi, Türk Dili ve Edebiyatı } \\
\text { Bölümü, Kayalı Kampüsü-Krrklareli/TÜRKKIYE } \\
\text { e-posta: editor@rumelide.com }\end{array}$} & $\begin{array}{l}\text { Adress } \\
\text { Kirklareli University, Faculty of Arts and Sciences, I } \\
\text { Turkish Language and Literature, Kayalı Campus-K } \\
\text { e-mail: editor@rumelide.com }\end{array}$ & $\begin{array}{l}\text { epar } \\
\text { rrklar }\end{array}$ & $\begin{array}{l}t \text { of } \\
\text { URKEY }\end{array}$ \\
\hline
\end{tabular}




\begin{tabular}{|c|c|c|c|}
\hline & Öğrencinin farklılıklara açık olmasını engeller. & 1 & 3.8 \\
\hline Toplam & & 26 & 100 \\
\hline
\end{tabular}

Yazınsal metinleri anlamaya yönelik etkinliklerin belirli bir kuram çerçevesinde tasarlanması gerektiğini düşünen öğretmenler, metne uygun kuram seçiminin metni anlamayı ve metne odaklanmayı kolaylaştıracağını; metin çözümlemesinin yapıldığı derslere düzen ve disiplin getireceğini; her metnin kendine özgü kazanımlarının ortaya çıkarılmasında etkili olabileceğini ifade etmişlerdir. Aynı zamanda öğretmenler belirli bir kuram doğrultusunda hazırlanan etkinliklerin metin çözümleme sürecini düzenleyeceğini, yöntemli hâle getireceğini ve sürecin niteliğini artıracağını belirtmişlerdir.

Yazınsal metinleri çözümleme etkinliklerinin bir kuram doğrultusunda tasarlanmaması gerektiği görüşünü belirten öğretmenler, her metne aynı metin çözümleme kuramı ile yaklaşmanın metnin yapısının göz ardı edilmesine neden olacağını, metin çözümleme sürecini kısıtlayacağını ve farklı düşünme biçimlerini engelleyeceğini ifade etmişlerdir. Öğretmenlerin bir kurama göre tasarlanan etkinliklerin öğrencilerin yaratıcı düşünmelerini engelleyeceği ve onları sınırlandıracağını düşündükleri görülmektedir.

\section{Türkçe öğretmenlerinin, yazınsal metinleri anlamaya yönelik etkinliklere ilişkin ek çalışma yapma durumları}

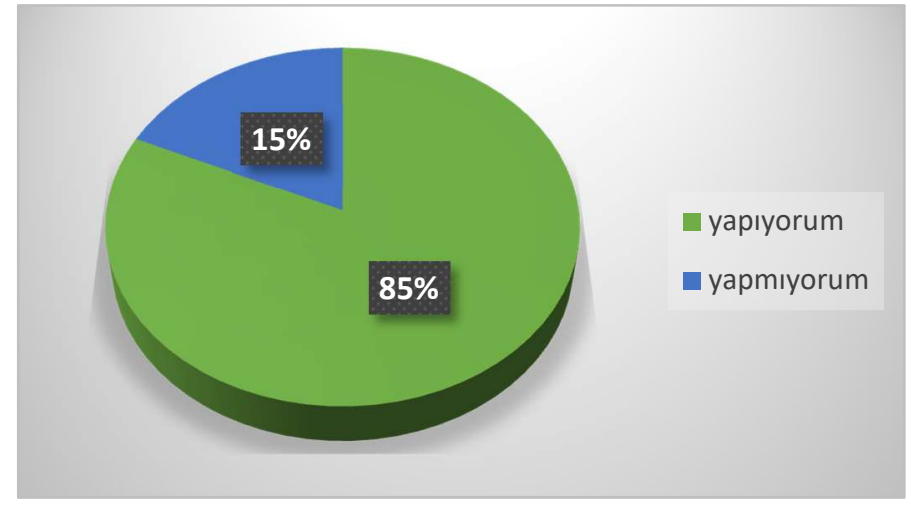

Şekil 5. Türkçe öğretmenlerinin "Yazınsal metinleri anlamaya yönelik etkinliklere ek çalışma yapıyor musunuz?” sorusu ile ilgili görüşleri

Türkçe öğretmenlerinin yazınsal metinleri anlamaya yönelik etkinliklere ek olarak çalışma yapma durumları Şekil 5'te sunulmuştur. Şekil 5'e göre Türkçe öğretmenlerinin \%85’inin yazınsal metinleri anlamaya yönelik etkinliklere ek çalışma yaptığı, \%15’inin ise ek çalışmaya gerek duymadığı anlaşılmaktadır.

Tablo 6. Türkçe öğretmenlerinin yazınsal metinleri anlamaya yönelik yaptıkları ek çalışmalar

\begin{tabular}{llcc}
\hline & & f & $\%$ \\
\hline \multirow{2}{*}{ Yapıorum } & Görsel-başlık yorumu & 1 & 2.5 \\
& Araştırma ödevi & 4 & 10.2
\end{tabular}




\begin{tabular}{|c|c|c|c|}
\hline & Canlandırma & 4 & 10.2 \\
\hline & Metinden hareketle metin oluşturma & 1 & 2.5 \\
\hline & Metni yeniden oluşturma & 1 & 2.5 \\
\hline & Farklı kaynaklardan (basılı, medya) bilgi toplama & 4 & 10.2 \\
\hline & $5 \mathrm{~N} 1 \mathrm{~K}$ & 1 & 2.5 \\
\hline & Özet çıkartma & 1 & 2.5 \\
\hline & Metin öncesi çalışmalar & 3 & 7.6 \\
\hline & Kurum/kuruluş ziyareti & 1 & 2.5 \\
\hline & Kendi yaşantısı ile metin arasında bağ kurma çalışmaları & 3 & 7.6 \\
\hline & Kitap tanitımı & 1 & 2.5 \\
\hline & Metindeki probleme yaratıcı çözümler bulma & 2 & 5.1 \\
\hline & Ek soru sorma & 1 & 2.5 \\
\hline & Şarkı dinletme, video izletme & 1 & 2.5 \\
\hline & Kavram haritası & 1 & 2.5 \\
\hline & İstasyon tekniği & 1 & 2.5 \\
\hline & Şiir ezberletme & 1 & 2.5 \\
\hline Yapmiyorum & Kitaptaki etkinlikleri yeterli buluyorum & 3 & 7.6 \\
\hline Toplam & & 39 & 100 \\
\hline
\end{tabular}

Tablo 6’ya göre yazınsal metinleri çözümleme etkinliklerine ek olarak öğretmenlerin, farklı kaynaklardan bilgi toplama ve araştırma yapma, canlandırma tekniğini kullanma, metin öncesi çalışmalara ağırlık verme, kendi yaşantısı ile bağ kurma, metindeki problemlere yaratıcı çözümler bulma gibi ek çalışmalar yaptıkları görülmektedir. Öğretmenlerin metin işleme sürecini öğrencilerin yaşantısından hareketle şekillendirecek ek çalışmalara yer vermeleri dikkat çekmektedir. Aynı zamanda öğretmenlerin farklı teknikleri uyguladıkları ek çalışmaları tercih etmeleri ise ders kitaplarında yer alan etkinlikleri bu bağlamda eksik veya yetersiz bulduklarını göstermektedir.

\section{Sonuç, Tartışma ve Öneriler}

Çalışmada elde edilen veriler ışığında aşağıdaki sonuçlara ulaşılmıştır:

1. Türkçe öğretmenlerinin, Türkçe ders kitaplarında yazınsal metinleri anlamaya yönelik etkinliklere yer verilmesi gerektiğini düşündükleri sonucuna ulaşılmıştır. Öğretmenler bu etkinliklerin, öğrencilerin okuma-anlama ve yorumlama becerilerine büyük katkıda bulunduğunu, anlatma becerisinin gelişmesi için anlama becerisinin gelişmesinin gerekli 
olduğunu ve bu gelişmenin de yazınsal metinleri anlamaya yönelik etkinliklerle sağlanacağını ifade etmişlerdir.

2. Türkçe ders kitaplarında yer alan yazınsal metinleri anlamaya yönelik etkinlikleri Türkçe öğretmenlerinin \%58'inin yetersiz, \%27'sinin yeterli, \%15’inin de kısmen yeterli bulduğu sonucuna ulaşılmıştır. Ders kitaplarındaki yazınsal metinleri anlamaya yönelik etkinlikleri yetersiz bulan öğretmenler yetersiz metinler seçilmesinin etkinliklerin niteliğini etkilediğini, etkinliklerin sayı ve içerik olarak metni kavramaya yetecek durumda olmadığını, etkinliklerin metnin içeriğinden kopuk olduğunu ifade etmişlerdir. Ders kitaplarındaki yazınsal metinleri anlamaya yönelik etkinlikleri kısmen yeterli bulan öğretmenler, bazı metinleri anlamaya yönelik etkinlikleri yeterli bazılarını ise yetersiz bulduklarını ifade etmişlerdir. Susar Kırmızı ve Akkaya (2009) yaptıkları çalışmada Türkçe öğretmenlerinin etkinliklerle ilgili olarak farklı görüşlere sahip olduklarını tespit etmişlerdir. Öğretmenlerin bir kısmı etkinliklerin fazla olduğunu ve sürenin yetersiz olduğunu ifade ederken bir kısmı da az olduğunu ve kendilerinin de yeni etkinlikler hazırlamadığını ifade etmiştir. Bu durum öğretmenlerin ders kitaplarında yer alan etkinlikler bağlamında öğretim programının onlara sağladığı esneklikten faydalanmalarının gerekliliğini ortaya koymaktadır. Öğretmenler yetersiz etkinliklerin yerine yeni etkinlikler hazırlayabilir veya var olan etkinliğin niteliğini artırarak öğrencilere sunabilirler.

3. Ders kitaplarındaki yazınsal metinleri anlamaya yönelik etkinlikleri yeterli bulan öğretmenler ise öğrencilerin kolay cevap verebilecekleri, metni kavramalarına yetecek sayı ve düzeyde etkinlikler olduğunu ifade etmişlerdir. Belirtilen görüşler öğretmenlerin, öğrencilerin seviyesine uygun etkinlikler yerine kolay cevap verebilecekleri etkinlikleri yeterli bulduklarını göstermektedir. Bu bağlamda, öğretmenler genellikle niceliksel bir tespit yapmış ve etkinliklerin niteliği hakkında görüş bildirmemişlerdir. Yazınsal metinleri çözümleme etkinliklerinin, öğrencilerin yazınsal metin aracılı̆̆ıyla hayat deneyimi elde etmelerini, metnin yüzey yapısından hareketle derin yapısındaki anlamları görmelerini, eleştirel ve yaratıcı düşünmelerini sağlayacak nitelikte olmasının daha önemli olduğu düşünülmektedir.

4. Türkçe öğretmenlerinin \%63’ünün Türkçe ders kitaplarında yer alan dil bilgisi etkinliklerinin yazınsal metinleri çözümleme etkinlikleri üzerinde etkili olmadığını, \%38'inin ise etkili olduğunu düşündükleri sonucuna ulaşılmıştır. Dil bilgisi etkinliklerinin yazınsal metinleri anlama bağlamında yetersiz olduğunu düşünen öğretmenler, dil bilgisi etkinliklerinde kullanılan cümlelerin metinden bağımsız olduğunu, bu etkinliklerin sadece gramer bilgisini geliştirdiğini, dil bilgisi etkinliklerinin yüzeysel ve metnin anlamına ulaşmada yetersiz olduğunu ifade etmişlerdir. Arıcı (2005) çalışmasında Türkçe öğretmenlerinin dil bilgisi etkinliklerini yetersiz bulduklarını, öğrencilerin bol örnekle ve uygun metinlerle karşılaşmaları lüzumunu ifade ettiklerini belirtir. Kılıç ve Akçay (2011) çalışmalarında Türkçe derslerinde yer alan metin inceleme çalışmalarında metinle ilişkili olarak dil bilgisi konularının işlenmesi gerektiğini belirtmişlerdir. Yapılandırıcı yaklaşım, dil öğretim yöntemlerinde de farklı yaklaşımların benimsenmesini sağlamıştır. Güneş (2013) yapılandırıcı yaklaşımla birlikte beceri yaklaşımı, etkinlik yaklaşımı ve tematik yaklaşımın önem kazandığını ifade etmiştir. Bu yaklaşımlar öğrencilerin dili kurallar bütünü olarak görmeleri yerine bağlam içerisinde öğrenmelerini sağlamaya yöneliktir. Dil bilgisi öğretimi, dil kullanımlarından yola çıarak dilin parça üstü birimlerinin işlevlerini sezdirmeli ve bu işlevlerin anlam üzerindeki etkisini ortaya çıkarmalıdır. Bunun için de en etkili öğrenme alanı metinlerdir. Ders kitaplarına seçilen yazınsal metinlerin, sezdirilecek dil bilgisi konusuna uygun ve konunun değişik yönlerini ortaya çıkaracak yeterlilikte olması metinle ilişkili dil bilgisi etkinliklerinin de niteliğini artıracaktır. 
5. Dil bilgisi etkinliklerinin yazınsal metinleri anlama bağlamında yeterli olduğunu düşünen öğretmenler ise bu etkinliklerin öğrencilerin metni anlamlandırmalarına yardımcı olduğunu, metinden seçilen cümleler üzerinde dil bilgisi çalışmaları yaparak öğrencilerin metni daha iyi kavradıklarını ve dil bilgisi konularına giriş sağladığını ifade etmişlerdir. öğretmenler hâlihazırda var olan etkinlikleri metin-dil bilgisi konusu-etkinlik bağlamında yeterli bulmuşlardır.

6. Türkçe öğretmenlerinin \%78,9'unun yazınsal metinleri anlamaya yönelik etkinliklerin belirli bir metin çözümleme kuramı çerçevesinde tasarlanmalı, \%26,3’ünün ise tasarlanmamalı görüşünde olduğu sonucuna ulaşılmıştır. Türkçe öğretmenleri belirli bir kuram doğrultusunda hazırlanan etkinliklerin öğrencilerin metne odaklanma gücünü geliştireceğini, dersin düzenli ve disiplinli ilerleyeceğini, metni kavramayı kolaylaştıracağını ve her metnin kendine özel kazanımlarının ortaya çıkmasında etkili olacağını ifade etmişlerdir. Öztokat (2005) metnin belirli bir yönteme bağlı kalınarak çözümlenmesinin diğer yöntemleri geçersiz veya yok saymak anlamına gelmediğini, metni belirli bir yöntem doğrultusunda çözümlemenin bilimsel tutarlılık, bütünsellik ve sürecin denetlenebilirliği noktasında nesnel ölçütler sunacağını ifade etmiştir. Metinlerin önemli bir araç olarak kullanıldığı Türkçe eğitiminin amaçlarından biri öğrencilerin okudukları metinden hareketle anlam oluşturmalarını sağlamaktır. Anlam oluşturma sürecinde metinlerin belirli bir yöntemle incelenmesi, metin çözümleme sürecinde öğrencilerin tutarlı bir biçimde metne ulaşmasını, etkinlikler arasındaki uyumun artmasıyla birlikte öğrencilerde bütünsel bir bakış açısının gelişmesini sağlayacaktır.

7. Yazınsal metinleri anlamaya yönelik etkinlikler belirli bir metin çözümleme kuramı çerçevesinde tasarlanmamalı görüşünde olan öğretmenler ise her metne aynı kuramla bakılmasının metnin kendine özgü yapısının ortaya çıkarılmasını engelleyeceğini ve öğrencinin metne bakışını kısıtlayacağını ifade etmişlerdir. Ders kitabında yer alan metinlerin tamamını ayını metin çözümleme kuramı çerçevesinde incelenmesi öğrencilerin tek yönlü bir bakış açısı edinmelerine neden olabilir. Bu süreçte her metnin kendi yapısına uygun ve farklı kuramlara dayanan yöntemler seçilebilir. Bir hikâye metnini çözümlemek için kullanılacak kuramla, şiir çözümleme için kullanılacak kuram aynı olmayabilir. Farklı kuramların seçilmesi öğrencilerin metne farklı açılardan yaklaşmasını kolaylaştıracak ve aynı zamanda öğretmene de tutarlı bir yöntem sunacaktır.

8. Türkçe öğretmenlerinin \%15’inin etkinliklere ek çalışma yapmadığı, \%85’inin ise ek çalışma yaptığı sonucuna ulaşılmıştır. Ek çalışma yapmayan öğretmenler kitaptaki etkinlikleri yeterli ve nitelikli bulduklarını ifade etmişlerdir. Ders kitaplarındaki etkinliklere ek çalışmalar yapan öğretmenler ise en çok canlandırma, araştırma, farklı kaynaklardan bilgi toplama, metin öncesi çalışmalar, öğrencinin yaşamı ile bağ kurma, yaratıcı düşünme çalışmaları yaptıklarını ifade etmişlerdir. Ancak öğretmenlerin ders kitabındaki etkinliklere alternatif olarak sunduğu görselbaşlık uyumu, özet çıkarma, metinden hareketle metin oluşturma gibi birçok etkinlik ders kitaplarında da yer almaktadır. Bu durumda öğretmenlerin bu çalışmalara ihtiyaç duydukları metinlerle ilişkili etkinliklerin yetersiz olduğu ifade edilebilir. Kurum-kuruluş ziyareti, canlandırma, kendi yaşantısıyla metin arasında bağ kurmaya yönelik etkinlikler öğretmenlerin doğrudan öğretim yerinde bilgiyi yapılandırmaya ve gerçek yaşamla bağ kurmaya yönelik çalışmaları benimsediklerini göstermektedir.

\section{Kaynakça}

Arıcı, A. F. (2005). İlköğretim okullarında dilbilgisi öğretimi üzerine öğretmen görüşleri. Kâzım Karabekir Eğitim Fakültesi Dergisi, (12), 52-60. 
Aydın, Ö. (1999). Orta okullarda dilbilgisi öğretimi üzerine öğretmen görüşleri. Dil Dergisi, 81, 23-29.

Aykaç, N. (2007). İlköğretim programında yer alan etkinliklerin öğretmen görüşleri doğrultusunda değerlendirilmesi (Sinop ili örneği). Ahi Evran Üniversitesi Kirşehir Eğitim Fakültesi Dergisi, 8 (2), 19-35.

Büyüköztürk, Ş., Kılıç Çakmak, E., Akgün, Ö. E., Karadeniz, Ş., \& Demirel, F. (2015). Bilimsel araştırma yöntemleri. (19. Basım). Ankara: Pegem Akademi.

Chen, Y. (2006). Using children's literature for reading and writing stories. Asian EFL Journal, 8(4), 210-232. $\quad$ https://www.asian-efl-journal.com/December_2006_EBook.pdf\#page=210 adresinden edinilmiştir.

Dilidüzgün, Ş. (2008). Türkçe öğretiminde metindilbilimsel bağlamda uygulamalı bir yaklaşım. Yayımlanmamış doktora tezi. İstanbul Üniversitesi Sosyal Bilimler Enstitüsü, İstanbul.

Dilidüzgün, Ş. (2010). Türkçe derslerinde metin etkinliklerinin okuma-anlama kazanımlarını gerçekleştirme yeterliği- bir öykü örneği. Hasan Ali Yücel Eğitim Fakültesi Dergisi, 7(1), 13-30. http://dergipark.gov.tr/iuhayefd/issue/8794/109901 adresinden edinilmiştir.

Epçaçan, C. \& Okçu, V. (2010). İlköğretim Türkçe ders kitaplarının öğretmen görüşleri doğrultusunda değerlendirilmesi. Milli Ĕ̆itim Dergisi, 4O(187), 39-51.

Göçer, A. (2010). Türkçe öğretiminde çok uyaranlı bir öğrenme ortamı oluşturmak için seçkin edebî ürünlerden yararlanma. Türklük Bilimi Araştırmaları Dergisi, (27), 341-369. http://dergipark.gov.tr/tubar/issue/16968/177238 adresinden edinilmiştir.

Göçer, A. \& Tabak, G. (2012). İlköğretim 5. Sinıf Türkçe öğrenci çalışma kitaplarının görsel okuma etkinlikleri bağlamında incelenmesi. İlköğretim Online, 11 (3), 790-799.

Günay, D. (2007). Metin bilgisi. İstanbul: Multilingual Yayınları.

Güneş, F. (2013). Türkçede metin öğretimi yerine metinle öğrenme. Adıyaman Üniversitesi Sosyal Bilimler Enstitüsü Dergisi, (11), 603-637.

Güven, A. Z. (2011). İlköğretim II. kademe Türkçe dersi öğretim programına ilişkin öğretmen görüşleri. Buca Eğitim Fakültesi Dergisi, 29, 121-133.

İpşiroğlu, Z. (2002). Türkçe yazın öğretimi nasıl çağdaşlaşacak?. Nasıl Bir Edebiyat Eğitimi içinde (ss. 79-88). İstanbul: Özgür Matbaacllı.

Karasakaloğlu, N. \& Bulut, B. (2012). Kurmaca metinlerin eleştirel okuma becerisini geliştirme aracı olarak kullanılması. Buca Eğitim Fakültesi Dergisi, (33), 95-109. http://dergipark.gov.tr/deubefd/issue/25117/265208 adresinden edinilmiştir.

Kılıç, M. \& Akçay, A. (2011). Türkçe öğretmen adaylarının görüşleri çerçevesinde dilbilgisi eğitimi. Sakarya University Journal of Education, 1 (1), 1-7.

Kolaç, E., Demir, T. \& Karadağ, R. (2012). Öğretmen adaylarının dil eğitiminde çocuk edebiyatı metinlerinin kullanımına yönelik görüssleri. Türkiye Sosyal Araştırmalar Dergisi, 161 (161), 195213.

Öztokat. T. N. (2005). Yazınsal metin çözümlemesinde kuramsal yaklaşımlar. İstanbul: Multilingual Yayınları.

Palamut, İ. (2008). Hikâye okumanın ilköğretim öğrencilerinin yaratıcllk düzeylerine ve akademik başarılarına etkisi. Yayımlanmamış yüksek lisans tezi. Dokuz Eylül Üniversitesi Eğitim Bilimleri Enstitüsü, İzmir.

Ramani, V. (2014). Short stories: an effective medium to improve language skills. International Journal of English: Literature, Language \& Skills, 3(1), 214-220. http://www.ijells.com/volume-3special-issue-1/ adresinden edinilmiştir.

Rifat, M. (1978). Dilbilim ve göstergebilim açısından yazınsal söylem. Dilbilim, (III), 101-104.

Sever, S. (2007). Çocuk ve edebiyat. (3. Baskı). Ankara: Kök Yayıncılık. 
Shazu, R. I. (2014). Use of literatüre in language teaching and learning: a critical assessment. Journal $\begin{array}{llll}\text { of Education } & \text { and } & \text { 39-35. }\end{array}$ http://iiste.org/Journals/index.php/JEP/article/view/11592 adresinden edinilmiştir.

Susar Kırmızı, F. \& Akkaya, N. (2009). Türkçe öğretimi programında yaşanan sorunlara ilişkin öğretmen görüşleri. Pamukkale Üniversitesi Eğitim Fakültesi Dergisi, 1 (25), 42-54.

Şahin, A. (2008). İlköğretim birinci sınıf Türkçe ders kitabı, öğrenci çalışma kitabı ve öğretmen kılavuz kitabının öğretmen görüşlerine dayalı olarak değerlendirilmesi. Ahi Evran Üniversitesi Kırşehir Ĕ̆itim Fakültesi Dergisi, 9 (3), 133-146.

Şahinli, A. (2008). Hikâye okumanın okuduğunu anlamaya ve Türkçe dersine yönelik tutuma etkisi. Yayımlanmamış yüksek lisans tezi. Dokuz Eylül Üniversitesi Eğitim Bilimleri Enstitüsü, İzmir.

Yaylı, D. \& Solak M. (2014). Ortaokul Türkçe ders kitaplarında ve öğretmen kılavuz kitaplarında yer alan yazma etkinliklerine dair öğretmen görüşleri. Turkish Studies, 9 (6), 1139-1151.

Yıldırım, A. \& Şimşek, H. (2011). Sosyal bilimlerde nitel araştırma yöntemleri. Ankara: Seçkin Yayıncilı. 